\title{
The Association of High Red Blood Cell Distribution Width with Metabolic Syndrome in Stable Coronary Artery Disease
}

\author{
(D) Kıvılcım Özden, (1) Aysun Erdem Yaman \\ Department of Cardiology, Siyami Ersek Cardiology and Cardiovascular Surgery Hospital, Istanbul, Turkey
}

\begin{abstract}
Introduction: Metabolic syndrome (MetS) increases the risk of cardiovascular diseases. The value of red blood cell width (RDW) has been demonstrated in several studies in coronary artery disease. This study aims to investigate the significance of RDW in MetS patients with coronary artery disease (CAD).

Methods: In this study, 120 of 89 patients undergoing coronary angiography were included. The whole group was divided into two groups according to coronary stenosis as noncritical and critical CAD. The study group was also divided into MetS and non-MetS. The cardiometabolic risk parameters were evaluated and RDW was calculated from complete blood count. Results: MetS prevalence was not significantly different between critic (71\%) and noncritical CAD (59.5\%) groups. RDW was significantly associated with MetS in the whole study population $(p=0.037)$ and was significantly higher in the critic-CADMetS group ( $p=0.018)$.

Discussion and Conclusion: RDW is an inflammation marker that is associated with MetS patients in CAD. The higher value of RDW is associated with critic-CAD. Future studies are needed to demonstrate the role of RDW on MetS to predict longterm cardiovascular events.

Keywords: Coronary artery disease; Metabolic syndrome; red blood cell distribution width; inflammation.
\end{abstract}

Corolir oronary artery disease (CAD) is a major cause of mortality and morbidity in developing countries. The rapidly increasing prevalence of metabolic syndrome and type 2 diabetes mellitus plays a fundamental role in this situation ${ }^{[1]}$.

The metabolic syndrome (MetS) first suggested by Reaven in $1988^{[2]}$ is a cluster of risk factors that increase the risk of cardiovascular diseases, hypertension, tip 2 diabetes mellitus, rheumatoid diseases, cancer, sleep apnea, nonalcoholic fatty liver, polycystic ovary disease and so on ${ }^{[3]}$.

Insulin resistance accompanying high insulin levels is the major underlying pathology that initiates the inflammation, vascular endothelium dysfunction and oxidative stress, all of which promote the development of atherosclerosis.

Red blood cell width (RDW) is defined as the quotient of the standard deviation of red blood cell volume and its mean volume and is expressed as the formula; RDW= (standard deviation of red blood cell volume/mean cell volume) $\times 100$. A great variation in red blood cell volume (anisocytosis) causes higher RDW values ${ }^{[4]}$.

Recent studies demonstrate that RDW is a new marker of inflammation, such as CRP, IL-1 and IL-6, and is associated with poor prognosis in coronary artery disease and myocardial infarction ${ }^{[5-7]}$. However, it has not yet been deter-

Correspondence (İletişim): Kıvılcım Özden, M.D. Siyami Ersek Kardiyoloji ve Kalp Damar Cerrahisi Hastanesi, Kardiyoloji Klinigi, Istanbul, Turkey Phone (Telefon): +90 5054549888 E-mail (E-posta): drkivilcim@yahoo.com 
mined whether RDW is only a marker of various disorders or is the cause of poor prognosis in patients with CAD.

The data on the relationship of RDW values with metabolic syndrome in CAD patients are unsatisfactory. However, the etiopathogenesis has not been completely clarified. It is mostly explained with underlying chronic inflammation and oxidative stress process ${ }^{[8,9]}$. Insulin resistance and high insulin levels may be responsible for high RDW by the influence of oxidative stress on red blood cells for shortening the life $\operatorname{span}^{[10]}$.

This study aims to demonstrate the relationship between cardiometabolic risk factors and RDW among patients with CAD suffering MetS.

\section{Materials and Methods}

\section{Study Population}

Our sample was derived from the 120 patients who were screened in our tertiary center from January to June and who had undergone elective coronary angiography with positive noninvasive test results. Eighty-nine patients (age $56 \pm 9.4$; mean \pm SD) were included in this study prospectively after the exclusion of the others. Inclusion criteria were age greater than 18 years old, a coronary angiogram clear enough to enable evaluation of cause of the positive stress test, patient's consent. Exclusion criteria were hematological disorders, anemia, malignancies, chemotherapy treatment and evidence of concomitant inflammatory disease, acute infection, chronic inflammatory conditions, and history of corticosteroid therapy in the preceding three months, cardiomyopathy, congenital heart disease. We conducted this study in accordance with the recommendations of the Helsinki Biomedical Research Declaration, involving human subjects. Our institutional ethical committee has approved this study, and we obtained informed consent from all patients.

\section{Study Procedure}

All the patients were examined, and baseline characteristics, including medical history, anthropometric measurements, risk factors for atherosclerosis and medications, were recorded. The population was divided into two coronary groups according to coronary lesions on coronary angiograms. The first noncritical CAD group had coronary arteries with the diameter stenosis of $<50 \%$ in one of the main epicardial artery, branch artery, or left main coronary artery. The second critical CAD group had $\geq 50 \%$ diameter stenosis in coronary arteries.
The venous blood sample was taken at admission before procedure after 12 hours of fasting for laboratory tests of complete blood count with the use of a Cell-Dyn ${ }^{\circledR} 3700$ (Abbott Laboratories; Abbott Park, III) and Clinical System (Beckman Coulter) for biochemistry and lipid values.

The patients suffering from MetS was determined according to the definition of the International Diabetes Federation (IDF) 2005 as follows:

Central obesity defined as waist circumference $\geq 94 \mathrm{~cm}$ (males) or $\geq 80 \mathrm{~cm}$ (females) plus any two of the following four factors:

1. Raised triglycerides $\geq 150 \mathrm{mg} / \mathrm{dl}$ or treatment for this lipid abnormality

2. Reduced $\mathrm{HDL}$ level $<40 \mathrm{mg} / \mathrm{dL}(1.03 \mathrm{mmol} / \mathrm{L})$ in males, $<50 \mathrm{mg} / \mathrm{dL}(1.29 \mathrm{mmol} / \mathrm{L})$ in females or specific treatment for this lipid abnormality.

3. Raised blood pressure (systolic BP $\geq 130$ or diastolic BP $\geq 85 \mathrm{~mm} \mathrm{Hg}$ ) or treatment of previously diagnosed hypertension

4. Raised fasting plasma glucose (FPG) $\geq 100 \mathrm{mg} / \mathrm{dL}$ (5.6 $\mathrm{mmol} / \mathrm{L}$ ) or previously diagnosed type 2 diabetes

\section{Statistical Study}

Continuous data were expressed as mean \pm standard deviation or median (inter-quartile range), and study groups were analyzed using Mann-Whitney-U tests for not normally distributed. Categorical variables were expressed as percentages and analyzed using chi-square test, Fisher's exact test, or Mantel Hansel test. Differences between groups were considered significant at $p<0.05$ two-sided. We investigated the effects of different variables on MetS and critical CAD by calculating odds ratios (ORs) in the linear regression model for continuous variables and logistic regression model for categorical variables. Statistical analyses were performed using SPSS 21.0 Statistical Package Program for Windows (SPSS Inc., Chicago, Illinois, USA).

\section{Results}

There were $21(23.3 \%)$ female and $68(75.6 \%)$ male in this study. The patients were divided into two groups by coronary angiographies as critical CAD and non-critical CAD. The whole population was also classified by the presence of the three criteria of MetS; like non MetS and MetS group. Subgroups were formed in critical CAD according to MetS presence. Critical CAD patients (59 \pm 8.8 ) were older than the patients $(53 \pm 9.4)$ in noncritical CAD $(p=0.007)$. Male dominance was observed $84.6 \%$ in critical CAD against $64.9 \%$ in noncritical CAD. Hemoglobin, RDW, 
mean platelet volume (MPV), C-reactive protein (CRP), triglycerides, fasting plasma glucose, low-density lipoprotein cholesterol (LDL-C) serum levels and waist circumference were not significantly different between groups. Body mass index (BMI) was significantly higher in critical CAD ( $p=0.032)$. Brain natriuretic peptide (BNP) level was significantly higher in critical CAD. High-density lipoprotein-C (HDL) level was prominently lower in the critical CAD group ( $p=0.033$ ) (Table 1$)$. In subgroup analysis, the patients with critical-CAD and MetS had significantly higher RDW values than the critic-CAD with non-MetS $(p=0.018)$. MetS was observed $66 \%$ among the total study population. MetS prevalence was not significantly different between critic (71\%) and noncritical CAD (59.5\%). The patients with MetS were significantly older than the patients with non-MetS $(p=0.011)$. There was no difference in sex between groups. Hemoglobin levels were significantly lower $(p=0.012)$ (Table 2$)$, and RDW levels were significantly higher $(p=0.037)$ in the MetS group (Fig. 1). Logistic regression analysis was performed to determine the predictors of metabolic syndrome. Univariance analysis revealed RDW as a predictor of MetS along with BMI, triglycerides, diabetes mellitus, hypertension and HDL-C levels. In multi-variance analysis, RDW was not an independent predictive factor of MetS (Table 3).

Table 1. Baseline characteristics according to CAD groups

\begin{tabular}{|c|c|c|c|}
\hline Values & $\begin{array}{c}\text { Critical CAD } \\
\quad(n=52)\end{array}$ & $\begin{array}{c}\text { Non-critical CAD } \\
(n=37)\end{array}$ & $\mathbf{p}$ \\
\hline Age (years) & $58.8 \pm 88$ & $54.4 \pm 9.4$ & 0.007 \\
\hline Male Sex, \% & 64.9 & 84.6 & 0.031 \\
\hline BMI $\left(\mathrm{kg} / \mathrm{m}^{2}\right)$ & $28.9 \pm 3.8$ & $30.4 \pm 4.5$ & 0.032 \\
\hline Waist circumference $(\mathrm{cm})$ & $102 \pm 10.4$ & $107 \pm 12.5$ & 0.339 \\
\hline Hemoglobin (mg/dl) & $14 \pm 1.8$ & $13.8 \pm 1.6$ & 0.62 \\
\hline RDW & $13.9 \pm 1.6$ & $13.4 \pm 1.8$ & 0.108 \\
\hline Platelets $\left(\times 10^{9} / \mu \mathrm{L}\right)$ & $230 \pm 64.9$ & $309.5 \pm 47.4$ & 0.242 \\
\hline MPV (fL) & $8.7 \pm 0.8$ & $9.1 \pm 1.1$ & NA \\
\hline Triglycerides (mg/dL) & $138 \pm 64.1$ & $140 \pm 82.9$ & 0.471 \\
\hline LDL-C (mg/dL) & $104 \pm 38$ & $101 \pm 34.3$ & 0.632 \\
\hline $\mathrm{HDL}-\mathrm{C}(\mathrm{mg} / \mathrm{dL})$ & $39 \pm 9.3$ & $44 \pm 9.1$ & 0.033 \\
\hline CRP & $0.2 \pm 0.73$ & $0.3 \pm 0.4$ & 0.632 \\
\hline BNP & $52.64 \pm 69.28$ & $18.04 \pm 80.03$ & 0.0003 \\
\hline fasting glucose (mg/dL) & $107.5 \pm 45.2$ & $98 \pm 40.5$ & 0.072 \\
\hline HBA1C & $6.1 \pm 1.15$ & $6 \pm 0.53$ & 0.062 \\
\hline MetS presence, $\%$ & 71.2 & 59.5 & 0.25 \\
\hline Hypertension, \% & 65.4 & 59.5 & 0.568 \\
\hline Diabetes mellitus, \% & 55.8 & 35.1 & 0.055 \\
\hline Smoking, \% & 21.2 & 18.9 & 0.796 \\
\hline
\end{tabular}

Results are presented as mean $\pm \mathrm{SD}\{$ median (inter-quartile range) $\}$ or number (percent).

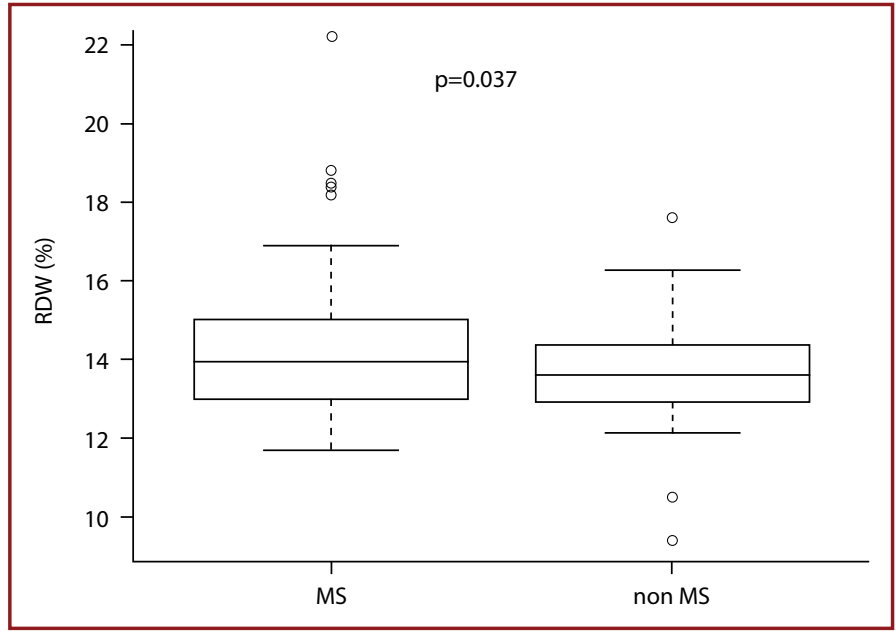

Figure 1. The graphic of the RDW value distribution amongst the MetS and non-MetS groups.

\section{Discussion}

Metabolic syndrome is a rapidly rising public health problem in the whole world. Industrialization and inappropriate nutrition habits are responsible for that increasing cluster of diseases. Thus, atherosclerosis starts in the early years of childhood. Global nutritional interventions are required to prevent metabolic syndrome. It is supposed that prothrombotic and pro-inflammatory processes, oxidative stress and endothelium dysfunction and adipose tissue dysfunction are underlying pathophysiological factors in MetS that initiate several diseases ${ }^{[11-13]}$.

Table 2. Baseline characteristics according to MetS presence

\begin{tabular}{|c|c|c|c|}
\hline Values & $\begin{array}{c}\text { MetS group } \\
\quad(n=59)\end{array}$ & $\begin{array}{c}\text { Non-MetS group } \\
(n=30)\end{array}$ & p \\
\hline Age (years) & $58.8 \pm 8.8$ & $54.4 \pm 9.4$ & 0.011 \\
\hline Sex & $43(\mathrm{M}), 16(\mathrm{~F})$ & $25(\mathrm{M}), 5(\mathrm{~F})$ & 0.272 \\
\hline BMI $\left(\mathrm{kg} / \mathrm{m}^{2}\right)$ & $30.4 \pm 3.8$ & $27.8 \pm 4.4$ & 0.002 \\
\hline Waist circumference $(\mathrm{cm})$ & $108 \pm 10.2$ & $98 \pm 10$ & 0.00001 \\
\hline Hemoglobin (mg/dl) & $13.6 \pm 1.8$ & $14.6 \pm 1.2$ & 0.012 \\
\hline RDW (\%) & $13.9 \pm 1.99$ & $13.4 \pm 0.9$ & 0.037 \\
\hline Platelets $\left(\times 10^{9} / \mu \mathrm{L}\right)$ & $230 \pm 65.3$ & $297 \pm 62.5$ & 0.327 \\
\hline MPV (fL) & $8.9 \pm 1.0$ & $8.9 \pm 1.0$ & 0.829 \\
\hline Triglycerides (mg/dL) & $161 \pm 74.6$ & $106.5 \pm 33.1<$ & $<0.00001$ \\
\hline $\mathrm{LDL}-\mathrm{C}(\mathrm{mg} / \mathrm{dL})$ & $100 \pm 36.3$ & $111.5 \pm 35.1$ & 0.066 \\
\hline $\mathrm{HDL}-\mathrm{C}(\mathrm{mg} / \mathrm{dL})$ & $38 \pm 8.5$ & $46.5 \pm 9.6$ & 0.0005 \\
\hline CRP (mg/dl) & $0.4 \pm 0.65$ & $0.1 \pm 0.58$ & 0.049 \\
\hline BNP (ng/L) & $40.6 \pm 85.93$ & $28.2 \pm 28.76$ & 0.126 \\
\hline Fasting glucose (mg/dl) & $112 \pm 43.9$ & $95 \pm 41$ & 0.00004 \\
\hline Hemoglobin A1c \% & $6.2 \pm 1.01$ & $5.9 \pm 0.79$ & 0.001 \\
\hline Hypertension, \% & 81 & 26.7 & $<0.0001$ \\
\hline Diabetes Mellitus, \% & 62 & 16.7 & $<0.0001$ \\
\hline Smoking, \% & 22 & 16.7 & 0.55 \\
\hline
\end{tabular}




\begin{tabular}{|c|c|c|c|c|}
\hline Values & $\begin{array}{c}\text { Univariance } \\
\text { Odds Ratio } \\
(95 \% \mathrm{CI})\end{array}$ & p & $\begin{array}{c}\text { Multi-Variance } \\
\text { Odds Ratio } \\
(95 \% \mathrm{CI})\end{array}$ & $\mathbf{p}$ \\
\hline MPV(fL) & $\begin{array}{c}1.04 \\
(0.67 / 1.63)\end{array}$ & 0.857 & & \\
\hline RDW & $\begin{array}{c}1.47 \\
(1.01 / 2.13)\end{array}$ & 0.042 & $\begin{array}{c}1.30 \\
(0.71 / 2.40)\end{array}$ & 0.399 \\
\hline BMI $\left(\mathrm{kg} / \mathrm{m}^{2}\right)$ & $\begin{array}{c}1.17 \\
(1.04 / 1.33)\end{array}$ & 0.012 & $\begin{array}{c}1.08 \\
(0.84 / 1.39)\end{array}$ & 0.568 \\
\hline Syntax score & $\begin{array}{c}1.04 \\
(0.98 / 1.09)\end{array}$ & 0.215 & & \\
\hline LDL-C (mg/dL) & $\begin{array}{c}0.99 \\
(0.98 / 1.001)\end{array}$ & 0.79 & & \\
\hline $\mathrm{HDL}-\mathrm{C}(\mathrm{mg} / \mathrm{dL})$ & $\begin{array}{c}0.92 \\
(0.87 / 0.97)\end{array}$ & 0.003 & $\begin{array}{c}0.79 \\
(0.64 / 0.97)\end{array}$ & 0.027 \\
\hline Triglycerides (mg/dL) & $\begin{array}{c}1.03 \\
(1.01 / 1.04)\end{array}$ & $<0.001$ & $\begin{array}{c}1.06 \\
(1.02 / 1.09)\end{array}$ & 0.003 \\
\hline Diabetes Mellitus & $\begin{array}{c}8.41 \\
(2.81 / 25.15)\end{array}$ & $<0.001$ & $\begin{array}{c}23.13 \\
(1.90 / 281.84)\end{array}$ & 0.014 \\
\hline Hypertension & $\begin{array}{c}12.0 \\
(4.24 / 33.99)\end{array}$ & $<0.001$ & $\begin{array}{c}274.73 \\
(8.60 / 8777.37)\end{array}$ & 0.001 \\
\hline Critical CAD presence & $\begin{array}{c}1.68 \\
(0.69 / 4.09)\end{array}$ & 0.252 & & \\
\hline
\end{tabular}

In recent years, in addition to known inflammation markers, so many studies have been conducted to clarify the significance of RDW in the assessment of patients with CAD. Osadnik et al. demonstrated that RDW was an independent risk factor for long-term mortality in stable coronary artery disease undergoing percutaneous coronary intervention $(\mathrm{PCl})^{[7]}$. In addition, RDW was related to the severity of CAD as regarding SYNTAX (SYNergy between PCI with TAXUS and Cardiac Surgery) ${ }^{[14]}$ and Gensin ${ }^{[15]}$ score in different studies. Tonelli et al. determined that RDW was a risk factor for myocardial infarction (MI), stroke, and symptomatic heart failure (HF) in patients with $C A D^{[5]}$. High RDW levels are also related to poor prognosis after $\mathrm{MI}$ in-hospital and long-term follow-up ${ }^{[6,16]}$.

Troms $\varnothing$ and National Health and Nutrition Examination Survey show that high RDW levels increase the risk of MI and mortality due to CAD in the population ${ }^{[17]}$.

The underlying mechanism of the relationship between poor prognosis of CAD and high RDW remains unclear. Factors impairing bone marrow hematopoietic function, iron metabolism, chronic inflammation ${ }^{[18,19]}$, vit D3 deficiency ${ }^{[20]}$, oxidative stress ${ }^{[10]}$ are possible causes of high RDW.

Tziakas et al. ${ }^{[21]}$ demonstrated that the cholesterol content of erythrocyte membrane (CEM) was associated with
RDW values and higher in patients with the acute coronary syndrome. Recent trials have demonstrated that when the erythrocytes gather in the necrotic core of the plaque, high CEM levels may cause vulnerable plaque, which points that red blood cells may actively encourage both plaque process and plaque instability $[22,23]$.

RDW was also significantly correlated with $\mathrm{HbA1c}$ in a study ${ }^{[24]}$ and with recent data from non-diabetic participants in the National Health and Nutrition Examination Survey (NHANES) study ${ }^{[25]}$. RBC survival rates are higher in subjects with high RDW, which causes a higher $\mathrm{HbA} 1 \mathrm{c}$ level because of the elevated duration of glucose exposure ${ }^{[24]}$. This may explain the positive relation between $\mathrm{HbA} 1 \mathrm{c}$ and RDW levels.

Although there are so many trials on RDW, researches on the relationship of RDW and metabolic syndrome and underlying possible causes are missing.

In our study, we observed that metabolic syndrome prevalence is so high in both critical (71.2\%) and noncritical CAD (59.5\%) groups. Hypertension prevalence was $62.9 \%$; diabetes mellitus was $47.2 \%$ in the study group.

Although we excluded patients with anemia in this study, hemoglobin levels were significantly lower in MetS pa-

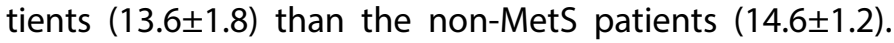
The reason for this relationship may be due to the iron metabolism impairment, or oxidative stress on erythrocyte membrane resulting in short lifespan and deformed erythrocytes ${ }^{[10]}$. The patients with MetS had significantly higher RDW values. In the subgroup analysis of critic-CAD, there was a significant difference in RDW values amongst MetS and non-MetS. The presence of MetS increases the RDW in critical CAD patients. RDW was a cofactor in the prediction of MetS patients in univariance regression analysis. The long-term predictive value of RDW in critical-CAD with MetS should be the aim of another research.

The recent trials on metabolic syndrome and RDW are as follows In the study of Farah et al., RDW was related to metabolic syndrome and patients meeting five criteria had higher RDW value than those meeting three criteria ${ }^{[26]}$.

In a large cohort study, 3529 patients undergoing coronary angiography were followed up to evaluate the relationship between RDW and MetS. In multivariate analysis, RDW values above $14 \%$ were independently associated with MetS and long-term all-cause mortality ${ }^{[27]}$.

Another study demonstrated high RDW values in overweight adolescents against to normal-weight adolescents. This study also revealed that in the mice model, nutritional changes increased RDW, whereas overweight per se did not change RDW[28]. 
Beyond the well-known major cardiometabolic risk factors, there is a need to identify new markers of MetS accompanying coronary artery disease. The markers may reflect underlying pathophysiology, predict future events, and can be used to assess the response to treatment. RDW and the other easily measured hematologic parameters may be new markers of metabolic syndrome as in coronary artery disease. Whether they play a role in pathophysiology or affected by the other factors should be searched in detailed trials.

\section{Study Limitations}

The limitation of our study is the small sample size. We excluded anemia and hematological diseases that may influence RDW levels, but we did not analyze the causes of elevated RDW values, such as iron, folic acid, or vitamin B12 deficiency.

\section{Conclusion}

Metabolic syndrome is an important cardiometabolic risk factor. It is crucial to identify the high-risk patients of CAD with MetS. RDW is a simple, easily detectable inflammatory marker that is widely predictive of poor prognosis in CAD patients. Our study shows that RDW is associated with MetS in CAD. The predictive value of the RDW on long-term prognosis of CAD accompanied CAD should be further confirmed in multi-center, prospectively designed studies.

Ethics Committee Approval: The Ethics Committee of Siyami Ersek Cardiology and Cardiovascular Surgery Hospital provided the ethics committee approval for this study (21.4.2016-2929).

Peer-review: Externally peer-reviewed.

Authorship Contributions: Concept: K.Ö.; Design: K.Ö.; Data Collection or Processing: A.E.Y.; Analysis or Interpretation: K.Ö.; Literature Search: A.E.Y.; Writing: K.Ö., A.E.Y.

Conflict of Interest: None declared.

Financial Disclosure: The authors declared that this study received no financial support.

\section{References}

1. Ford ES. The metabolic syndrome and mortality from cardiovascular disease and all-causes: findings from the National Health and Nutrition Examination Survey II Mortality Study. Atherosclerosis 2004;173:309-14. [CrossRef]

2. Reaven GM. Banting lecture 1988. Role of insulin resistance in human disease. Diabetes 1988;37:1595-607. [CrossRef]

3. Reaven GM. The metabolic syndrome: requiescat in pace. Clin Chem 2005;51:931-8. [CrossRef]

4. Karnad A, Poskitt TR. The automated complete blood cell count. Use of the red blood cell volume distribution width and mean platelet volume in evaluating anemia and thrombocytopenia. Arch Intern Med 1985;145:1270-2. [CrossRef]
5. Tonelli M, Sacks F, Arnold M, Moye L, Davis B, Pfeffer M; for the Cholesterol and Recurrent Events (CARE) Trial Investigators. Relation Between Red Blood Cell Distribution Width and Cardiovascular Event Rate in People With Coronary Disease. Circulation 2008;117:163-8. [CrossRef]

6. Sun XP, Chen WM, Sun ZJ, Ding XS, Gao XY, Liang SW, et al. Impact of red blood cell distribution width on long-term mortality in patients with ST-elevation myocardial infarction. Cardiology 2014;128:343-8. [CrossRef]

7. Osadnik T, Strzelczyk J, Hawranek M, Lekston A, Wasilewski J, Kurek $A$, et al. Red cell distribution width is associated with long-term prognosis in patients with stable coronary artery disease. BMC Cardiovasc Disord 2013;13:113. [CrossRef]

8. Lippi G, Targher G, Montagnana M, Salvagno GL, Zoppini G, Guidi GC. Relation between red blood cell distribution width and inflammatory biomarkers in a large cohort of unselected outpatients. Arch Pathol Lab Med 2009;133:628-32.

9. Zhang PY, Xu X, Li XC. Cardiovascular diseases: oxidative damage and antioxidant protection. Eur Rev Med Pharmacol Sci 2014;18:3091-6.

10. Friedman JS, Lopez MF, Fleming MD, Rivera A, Martin FM, Welsh $M L$, et al. SOD2-deficiency anemia: protein oxidation and altered protein expression reveal targets of damage, stress response, and antioxidant responsiveness. Blood 2004;104:2565-73. [CrossRef]

11. Serné EH, de Jongh RT, Eringa EC, IJzerman RG, Stehouwer CD. Microvascular dysfunction: a potential pathophysiological role in the metabolic syndrome. Hypertension 2007;50:20411. [CrossRef]

12. Elnakish MT, Hassanain HH, Janssen PM, Angelos MG, Khan $M$. Emerging role of oxidative stress in metabolic syndrome and cardiovascular diseases: important role of Rac/NADPH oxidase. J Pathol 2013;231:290-300. [CrossRef]

13. Yubero-Serrano EM, Delgado-Lista J, Peña-Orihuela P, PerezMartinez $P$, Fuentes F, Marin C, et al. Oxidative stress is associated with the number of components of metabolic syndrome: LIPGENE study. Exp Mol Med 2013;45:e28. [CrossRef]

14. Akin F, Köse N, Ayça B, Katkat F, Duran M, Uysal OK, et al. Relation between red cell distribution width and severity of coronary artery disease in patients with acute myocardial infarction. Angiology 2013;64:592-6. [CrossRef]

15. Ma FL, Li S, Li XL, Liu J, Qing P, Guo YL, et al. Correlation of red cell distribution width with the severity of coronary artery disease: a large Chinese cohort study from a single center. Chin Med J (Engl) 2013;126:1053-7.

16. Veeranna V, Zalawadiya SK, Panaich S, Patel KV, Afonso L. Comparative analysis of red cell distribution width and high sensitivity C-reactive protein for coronary heart disease mortality prediction in multi-ethnic population: findings from the 1999-2004 NHANES. Int J Cardiol 2013;168:5156-61. [CrossRef]

17. Borné Y, Smith JG, Melander O, Engström G. Red cell distribution width in relation to incidence of coronary events and case fatality rates: a population-based cohort study. Heart 2014;100:1119-24. [CrossRef] 
18. Ponikowska B, Suchocki T, Paleczny B, Olesinska M, Powierza $S$, Borodulin-Nadzieja $L$, et al. Iron status and survival in diabetic patients with coronary artery disease. Diabetes Care 2013;36:4147-56. [CrossRef]

19. Pierce CN, Larson DF. Inflammatory cytokine inhibition of erythropoiesis in patients implanted with a mechanical circulatory assist device. Perfusion 2005;20:83-90.[CrossRef]

20. Kunadian V, Ford GA, Bawamia B, Qiu W, Manson JE. Vitamin $D$ deficiency and coronary artery disease: a review of the evidence. Am Heart J 2014;167:283-291. [CrossRef]

21. Tziakas D, Chalikias G, Grapsa A, Gioka T, Tentes I, Konstantinides $S$. Red blood cell distribution width: a strong prognostic marker in cardiovascular disease: is associated with cholesterol content of erythrocyte membrane. Clin Hemorheol Microcirc 2012;51:243-54. [CrossRef]

22. Tziakas DN, Kaski JC, Chalikias GK, Romero C, Fredericks S, Tentes IK, Kortsaris AX, Hatseras DI, Holt DW. Total cholesterol content of erythrocyte membranes is increased in patients with acute coronary syndrome: a new marker of clinical instability? J Am Coll Cardiol 2007;49:2081-9. [CrossRef]

23. Yu MM, Xu Y, Zhang JH, Wang CH, Wang XC, Cheng ZP, et al. Total cholesterol content of erythrocyte membranes lev- els are associated with the presence of acute coronary syndrome and high sensitivity C-reactive protein. Int J Cardiol 2010;145:57-8. [CrossRef]

24. Engström G, Smith JG, Persson M, Nilsson PM, Melander O, Hedblad B. Red cell distribution width, haemoglobin A1c and incidence of diabetes mellitus. J Intern Med 2014;276:174-83.

25. Zalawadiya SK, Veeranna V, Panaich SS, Afonso L. Red cell distribution width and risk of peripheral artery disease: analysis of National Health and Nutrition Examination Survey 19992004. Vasc Med 2012;17:155-63. [CrossRef]

26. Farah R, Khamisy-Farah R. Significance of MPV, RDW with the Presence and Severity of Metabolic Syndrome. Exp Clin Endocrinol Diabetes 2015;123:567-70. [CrossRef]

27. Laufer Perl M, Havakuk O, Finkelstein A, Halkin A, Revivo M, Elbaz $M$, et al. High red blood cell distribution width is associated with the metabolic syndrome. Clin Hemorheol Microcirc 2015;63:35-43. [CrossRef]

28. Fujita B, Strodthoff D, Fritzenwanger M, Pfeil A, Ferrari M, Goebel $B$, et al. Altered red blood cell distribution width in overweight adolescents and its association with markers of inflammation. Pediatr Obes 2013;8:385-91. [CrossRef] 